\title{
9 オゾンガス隇菌法の研究
}

古橋正吉, 上田伊佐雄（東京医科歯科大）

[目的]オン゙ン (OZONE) ガスの隇菌効果につい て研究した．オン゙ンガスは利用の仕方によって減菌後 の残留毒性の問題や引火爆発の危険がない, 反面, 反 応性が強く不安定な物質である. 今回は, オン゙ンガス 濃度, 温度, 湿度, 曝露時間等の条件別溦生物（細 菌芽胞等）の死隇効果を研究したので報告する.

[方法] 実験装置はオゾンガス発生機（沿面放電方 式), 隇菌槽 (18L 容積), 触媒槽, 排気用ポンプ呿よ びダクト等で構成したものを用いた。 ガス濃度は紫外 吸収式濃度計で連続測定した。

供試菌は, Bacillus subtilis, B. stearothermophilus, B. pumilus (spore : 菌量 $10^{4} \sim 10^{8}$ ) と Aspergillus niger (conidium: $10^{3}$ ) の 4 菌種を用い た. オゾン濃度は 80 100 ppm, 作用温度 $20 \sim 50^{\circ} \mathrm{C}$, 作用時間は 1 時間ないし 6 時間の範囲とした.

〔成績】オン゙ン濃度平均 $80 \mathrm{ppm}, 24^{\circ} \mathrm{C} ， 1$ 時間曝
露では Aspergillus niger は死隇したが他の供試菌 (10 $)$ は死隇せず, $50^{\circ} \mathrm{C}, 2 \sim 4$ 時間曝露でも同様の 成績であった。 しかし， $21^{\circ} \mathrm{C} ， 6$ 時間暴露では， B. subtilis $\left(10^{6}\right)$ はすべて死隇 ᄂ, B. pumilus $\left(10^{6}\right)$ の死減率は $80 \%$ であった。この点をさらに検討した 結果, 滅菌工程に打いて加温, 加湿条件を適宜組み合 わせることで滅菌効果を高めることが明らかになっ た.

[考察】オゾンガス隇菌を完成するパラメータはガ ス濃度，温度，湿度扣よび作用時間である，とりわけ 加温, 加湿条件の設定に工夫することが重要であるこ とが判明した. この成績は, 低温下保存の医療材料, 薬品, 食品等の隇菌実施に有用な示唆を与えている. 次の研究ではオゾンガスの浸透性を高める手段拉よび 独自の包装材料の開発につとめたいと考穴ている.

\section{0 回路内消毒器の使用経験}

神田橋忠, 高 橋成 輔 (九州大麻醉科蘇生科) 松田和久, 兒玉謙 次 (九州大手術部)

[目的]循環式麻酷器は, 麻醉管理に不可欠な機器 であるが，一度微生物により污染された場合, その回 路内は複雑で消毒は困難である. 今回我々は, 回路内 消毒器（フコマ MF-60) を麻醉器回路に使用する経 験を得，その効果を調査したので報告する。

[方法]

1) 普通寒天培地飞 4 種の細菌 (Staphylococcus aureus, MRSA, E. coli, Pseudomonas aeruginosa) を塗布直後と24時間培養したものをキャニスター内に 設置し消毒する。

2) 回路内の各部 (呼気升, 吸気升, キャニスター 上部・下部の内壁, 呼吸バッグロ）に菌を塗布し, そ の直後消毒する，消毒薬として消毒用アルコールを用 い，消毒時間は，10，20，30，60，90分とし，培養は $37^{\circ} \mathrm{C} ， 7$ 日間とした.

[結果]

1）普通寒天培地汇細菌を塗布 直 後消毒したもの
は，10，20，30，60，90分の消毒で 4 菌種とも発育を 認めなかった。

2) 普通寒天培地に 24 時間培養したものを消毒した 場合, 10,20,30分の消毒では MRSA と Pseudomonas aeruginosa の発育を認めたが, 60,90 分の 消毒では 4 菌種とも発育を認めなかった。

3) 回路内の各部所に直接菌を塗布しその直後消毒 した場合，菌の検出は全て認められなかった。

[考察]本器は，60，90分の消毒で良好な消毒効果 を示した. しかし，30分以下の消毒では24時間培養し た MRSA と Pseudomonas aeruginosa を死隇でき ず，この状態では菌量に比べ消毒薬の量と作用時間が 不十分であったと考学られた，本器は，ホルマリンに 比べ, 人を機器への影響る少なく安全に使用でき有用 であると思われるが，60分未満の消毒工程について は，消毒時間と細菌負荷量・培養状態等さらに検討が 必要と思われる. 